\title{
Public Relations Strategies for Conflict Management in Agape Gospel Mission Inc.
}

\author{
Vincent I. Edafejirhaye ${ }^{1}$, Ayotunde Alao $^{2}$ \\ ${ }^{1}$ Department of Mass Communication, Adeleke University, Ede, Nigeria \\ ${ }^{2}$ Adeleke University, Ede, Nigeria \\ Email: Jirhaye207vi@gmail.com,drayotunde@gmail.com
}

How to cite this paper: Edafejirhaye, V.I. and Alao, A. (2019) Public Relations Strategies for Conflict Management in Agape Gospel Mission Inc.. Open Access Library Journal, 6: e5727.

https://doi.org/10.4236/oalib.1105727

Received: August 23, 2019

Accepted: September 23, 2019

Published: September 26, 2019

Copyright $\odot 2019$ by author(s) and Open Access Library Inc.

This work is licensed under the Creative Commons Attribution International License (CC BY 4.0).

http://creativecommons.org/licenses/by/4.0/

(c) (i) Open Access

\begin{abstract}
This study investigated the use of Public Relations strategies in conflict management in Agape Gospel Mission. The in-depth interview methodology was used to elicit data and the findings show that Agape gospel mission is using public relations tools such as dialogue, persuasion, negotiation, mediation and arbitration in managing conflicts. The study recommends the PR tools for other churches especially Pentecostal churches to manage conflicts in their organizations.
\end{abstract}

\section{Subject Areas}

Journalism and Communication

\section{Keywords}

Public Relations, Conflict, Management, Strategy

\section{Introduction}

Public relations as Ibrahim observes is a field of communication and conflict as a phenomenon; both are society-oriented having humans as a centre of focus. In every society there is no such thing as conflict in the absence of humans [1]. If human beings generate conflicts at the societal context in which they exist, they also invariably need some balance in conflict position to ease up or ameliorate the negative effects of conflict. One of the balancing measures communication scholars offer as effective panacea to conflict management is public relations strategic communication. According to Ibrahim:

Human beings who are the objects of strategic public relations are more complex; it is therefore, believed that strategic public relations is faced with the challenges of unraveling and simplifying the complexity of human nature in order to 
ensure sound understanding between actors in conflict [1].

Public relations strategic communication from Ibrahim's point of view is the skillful application of public relations strategies in addressing negative situations with the aim of converting such to positive essentials for the benefits of humanity. In establishing the functions of Public relations, Black classified them into thirteen [2]. His classification suggests that public relations functions as counseling tool in understanding human behaviour, analyzing future trends and predicting their consequences; research into public opinions, attitudes, expectations and advising on necessary actions; establishing and maintaining two-way communication based on truth and full information, preventing and managing conflict and misunderstanding; promoting mutual respect and social responsibility, harmonizing the private and the public interest, promoting goodwill with staff, suppliers and customers, improving industrial relations, promotion of products and services; attracting good personnel and reducing labour turn over; maximizing profitability and projecting corporate identity [3]. Nwosu in the same vein, opines that Public relations is a profession that influences public opinions or attitudes in a positive direction; promoting understanding and acceptance. He further notes that public relations establishes two-way communication in the resolution of conflicts of interest between individuals, organizations and its publics. The British Institute of Public Relations (BIPR) defines Public Relations Practice as "deliberate, planned and sustained effort to establish and maintain mutual understanding between an organization and its publics" [4]. Public relations practitioners at a world conference in Mexico City in 1978, provided a popular definition called the Mexican Statement. It stated that:

Public relations is the art and social science of analyzing trends, predicting its consequences, counseling organization leaders, and implementing planned programmes of action which will serve both the organization and the public interests [4].

From the above explanations, public relations helps complex, pluralistic society to reach decisions and functions more effectively by contributing to mutual understanding among groups and institutions. It serves to bring private and public policies into harmony. Public Relations serves a wide variety of institutions in society such as business, trade unions, government agencies, voluntary associations, foundations, hospitals, educational and religious institutions. To achieve their goals, these institutions develop effective relationships with different audiences or publics such as employees, church leaders, church members, consumers, local communities, shareholders and other institutions in the society at large.

The word conflict can be understood if the following synonyms are employed-clash, tension, crisis, struggle or friction. Although these words are inadequate in themselves, in providing acceptable definition, they are reoccurring decimal of a typical conflict [5]. Hoff observes areas of frequent conflict which include money, power, position seeking, value, beliefs and loyalty to persons and groups [6]. Cosers also define conflict as "a struggle over values and claims to scarce status, power and resources in which the aims of the opponents are to 
neutralize, inspire or eliminate their rivals". Ledingham sees conflict as struggle for power by contending forces [7]. It is a clash of view or a difference of opinion between individuals or groups, which should be managed for organizations to achieve set goals. Oji in agreement with Deutsch opine that conflict management starts where conflict resolution fails to end a conflict. Management of conflict becomes the best option in instances where conflict involves non negotiable human needs and is deep-rooted and resistant to resolution [8] [9]. There are various ways conflicts are managed; these include integration, obliging, dominating, avoiding and collaborating. Conflict management according to Laderach becomes an inevitable factor since conflict is pervasive among people, groups, organization, communities, multi-national companies and the international communities [10].

Churches are not immune to conflicts since human beings that constitute the congregations have various background, disposition, education and expectations and their actions and reactions may vary. In reality, a measure of vibrancy of the evangelical and Pentecostal church congregation would necessarily be not the absence of conflict, but the way the leadership manages the situation. Application of public relations strategies in church administration will go a long way in promoting harmony and smooth operations of church activities, programmes and administration. There are various public relations strategies used in conflict management. They include dialogue, mediation, negotiation, arbitration, community relations and many others [11] [12]. In conflict management, communication scholars observe that public relations remained a veritable instrument [1] [12] [13].

It is against this background this study seeks to examine the conflict situations in Agape Gospel Mission Inc. and the various strategies they used to manage those conflicts.

Agape Gospel Mission is one of the Pentecostal churches in Nigeria founded by an American Missionary Rev. Richard Whitcomb in Sapele in the year 1983 [14]. Later the headquarters was moved to Effurun, near Warri in Delta state, Nigeria. The Church has over 100 local churches in Delta state and has spread to some African countries such as Ghana, Republic of Benin, Togo and also America according to the information in their website. The church has been experiencing various conflict situations since 1993. Some of such conflicts are leadership tussle, transfer issues, immorality, monetary issues, conflict of opinion and many others. These conflict situations have slow down the church growth to some extent; promote open quarrel, physical attack and breakaway of some of the branches. The leadership of the Mission through the leading of the Holy Spirit employed Public relations strategies to managing the above conflict situations which could be source of learning to other churches in Nigeria and the global community (Figure 1).

\section{Statement of the Problem}

From Fernadez's point of view Conflict is found everywhere in the society in all 


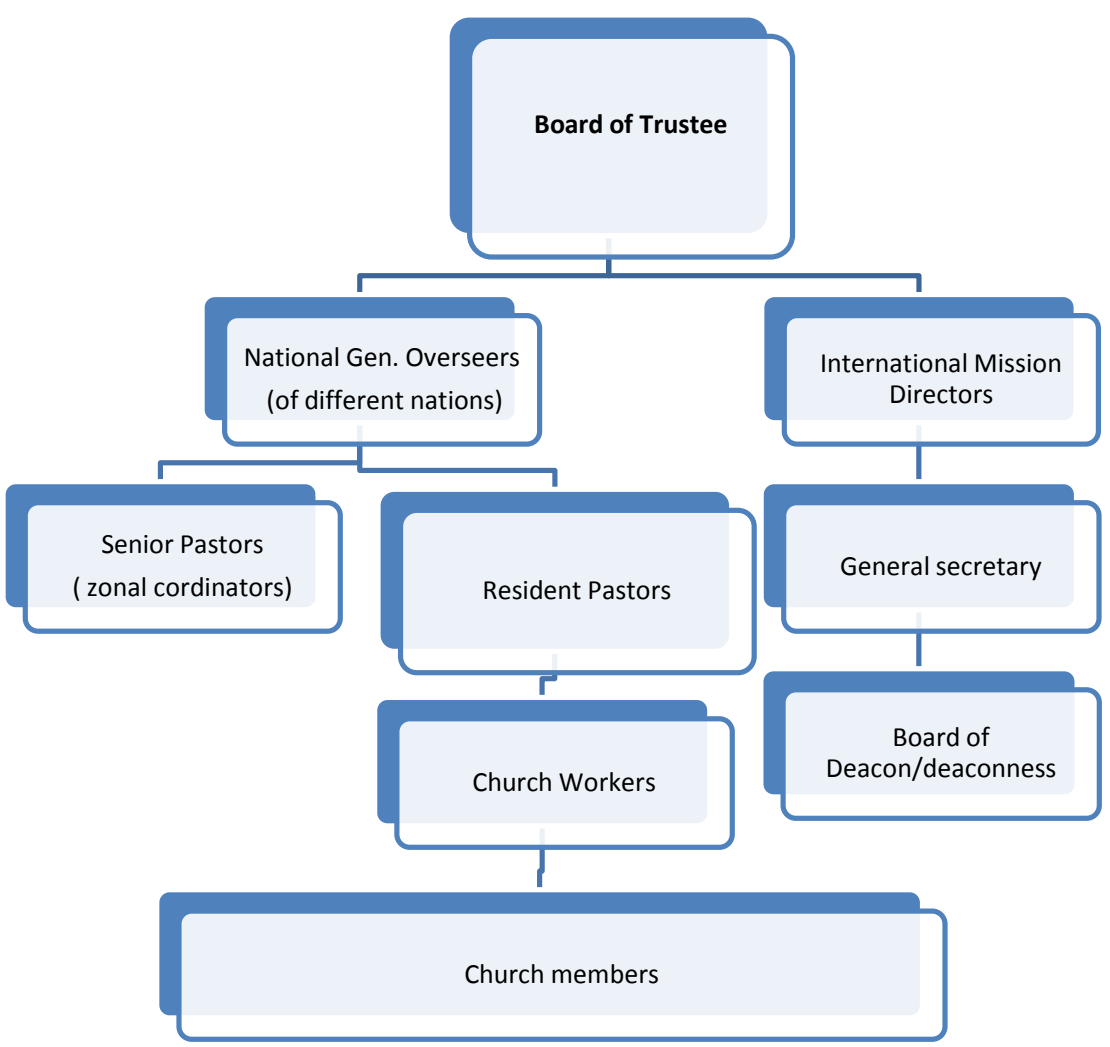

Figure 1. Organigram of Agape Gospel Mission Inc. Source: Edafejirhaye field research [15].

aspects of life where human beings interact with one another [16]. When there is communication breakdown among people there is bound to be conflict. Conflict in churches can lead to disintegration, fighting, public assault and death. When conflicts occur the general society shares in the consequences. Perhaps; the idea of managing such conflicts using Public relations strategies could effectively minimizing conflict in the church. For instance, the conflict in Church of God which led to the establishment of Bathesda Gospel Mission, Irri in Isoko South local government in the 1980s claimed some lives and properties; and it almost snowballed into tribal war between the Isoko and the Edo people. The emergence of Word of Life Bible Church in Warri was as a result of friction between the late Archbishop BensonIdahosa and Pastor Ayo Oritseja for over transfer of Pastor Ayo from Praise Centre, Jakpa in Effurun. The congregation was not happy about the transfer hence; some members encouraged Pastor Ayo to break away. The Mountain of Fire and Miracle broke away from Deeper Life Bible Church because of doctrinal differences [17] [18]. Duval and Ojo write on series of congregational and leadership conflicts which took place at the inception of the Baptist Mission. According to them, the conflict led to rapid spread of Baptist local Churches in Lagos and other parts of Nigeria due to the ways the leadership managed the conflict situations. In Agape Gospel Mission, leadership conflict facilitated the spread of the Mission to some West African countries 
such as Ghana, Togo, Republic of Benin and others; though it has serious effects on the spiritual growth of the branches in Nigeria for a long time. From personal observation, it seems that Church politics, disloyalty, oppression, financial mismanagement, tussle for leadership positions and divisions among members have characterized the management of indigenous evangelical and Pentecostal churches in Nigeria particularly in the last three decades of the twentieth century. Perhaps, the major factors for the occurrences in the Nigerian indigenous Christianity in recent times could be traced to doctrinal practices, leadership problems, different interpretations and manipulations of prophetic gifts and other issues. Today, some church pioneers have been alleged of playing double standard in the running of church affairs. Some also have been accused of false biblical teachings resulting at times to fake prophecies and revelations. These attitudes may have negative implications on the society. In the light of this, this study investigated the causes, nature and effects of conflict in Agape Gospel Mission and explores the strategies used to address the situation.

\section{Objectives of the Study}

The objective of the study is to investigate the use of Public Relations strategies in conflict management in Agape church.

The specific objectives are to:

1) Verify major causes of the conflicts in Agape Gospel Mission

2) Identify Public Relations strategies used by the church in conflict management.

\section{Research Questions}

1) What are the causes of conflict in Agape Gospel Mission?

2) To what extent are Public Relations strategies used in Agape Gospel Mission for conflict Management?

\section{Theoretical Framework}

A study of Public Relations and conflict management demands that Public relations theory and suitable conflict management theories should be examined. Broadly defined, theories are "set of interrelated generalizations, combined in such a way that they form a logical system of explanation in which one generalization does not contradict another" [19]. It is simply a "set of related propositions that presents a systematic view of phenomenon by specifying relationship among concepts" [20] [21]. A good theory should clearly explain why a particular concept should behave in a particular way. This is why argues that "a good theory explains an event or behaviour [22]. It brings clarity to an otherwise jumbled situation. It draws order out of chaos". A good theory must therefore clarify confusing situations. It should of necessity, "ventilate a situation or event that appears nebulous to the extent that it would guarantee concrete, precise and detailed understanding of the situation or event" [3]. The purpose of this section 
therefore is to explore certain schools of thought on the causes of conflict and to attempt to explain the conflicts in Nigerian Churches and how they could be managed. There is a large volume of literature written about the nature and theories of conflict, but because of the purpose of this paper, Public relations Psychodynamic Model, Transfer Process Model and Eclectic (Hybrid) theories of conflict management will be used.

\subsection{The Psychodynamic Model}

Psychodynamic model is a Public relations theory borrowed from the field of psychology. It was propounded by Sigmund Freud in 1900. The assumptions of the theory according to Anaeto, Onabajo and Osifeso are:

1) It looks at mental processes.

2) It is concerned about motivations that are linked to the psychology of personality.

3) It focuses on the inherent motivations and how bad behaviour could be changed by breaking of bad habits [23].

[19] The theory according to De Fleur and Ball-Rokeach is based on individual differences perspective, postulating that for persuasive messages to be considered effective, they must succeed in altering the psychological orientation of the target people in such a way that they will respond openly with behaviour model desired and intended by the communicator. In Nigerian churches where conflict becomes regular occurrence resulting in killing, destruction of property, kidnapping of pastors, frustrating pastors by using transfer and some cases using hired assassin to intimidate church leaders; using the model in view as Mogu observes, public relations experts through persuasion can identify the causes of conflict in the churches and design strategic messages for targeted church workers and leaders [24]. Through this, the psychological orientation of church workers, Pastors and Mission leaders will be openly modified as desired by the public relations experts.

\subsection{The Transfer Process Model}

The Public relations transfer Process Model was propounded by Frank Jefkins in 1988. The thesis of the theory is that negative situations could be converted to positive achievement through appropriate communication processes thereby creating mutual understanding. It explains how communication experts could use and apply public relations tools and strategies towards changing hostile situations in Churches, organization and government from hostility to sympathy, prejudice to acceptance, apathy to interest and ignorance to knowledge [25] [26]. The transfer process model according to Oji is an antidote to organizational conflict which addresses all negative attitudes such as [8]:

1) Hostility: This suggests that every organization has hostile publics who at one time or the other will be hostile towards its programmes and activities. It is the role of public relations to arouse the sympathy of such publics towards the 
organization.

2) Prejudice: At a particular time, every organization vis-à-vis church has publics who do not want to hear or agree with the programmes and activities of the organization. Such prejudice may be borne out of educational backgrounds, parental care, religions, social or class influences, environmental or societal factors. It is the duty of public relations to change such prejudices to acceptance of the organization by the publics.

3) Apathy: This means there are enemies of understanding that do not want to have anything to do with the products, programmes, services or activities of the organization and therefore lack feeling or desire to act in any way towards the organization. Such apathy may be as a result of selfishness, laziness, shallow understanding, lack of faith in the organization's activities. It is the responsibility of public relations to inspire or arouse the interest of such publics towards the organization.

4) Ignorance: This is the failure of organization to make known to its internal and external publics various changes in progammes and activities which will improve the fortune of the organization. Public relations is duty bound to promote knowledge and understanding in order to wipe away ignorance.

From the foregoing, organizations, government institutions and the church could use the Jefkins' public relations process model to win the goodwill of the public to reduce conflict level.

\subsection{The Eclectic (Hybrid) Theories}

These are group of conflict theories borrowed from the field of psychology which explain causes and management of conflict. The basic assumption of the eclectic theories is that behaviour is governed by both inherent and contingency factors and they cannot be separated [27].

[28] Cunningham explains that the eclectic theories argue that civil conflicts are products of multiple factors. Factors leading to a conflict may be political, social, economic, historical, spiritual, cultural, and psychological. Due to the complexity nature of church conflicts, communication scholars such as Tiwell, Kurt Lewin and Skinner argue that a single variable cannot explain the causes of conflict [29] [30]. Tidwell also situates Kurt Lewin's "Field Theory" in this category because it attempts to integrate both individual behaviour and social context in conflict. Lewin demonstrates that both the individual and the group are interdependent and therefore, both are responsible for conflict [27]. Therefore, in the explanation of conflict, there is a convergence of human behaviour which is inherent and human behaviour which is contingent.

[3] Kieh as cited in Akanji also contends that eclectic theories suggest two basic causes of conflict in every conflict. On the one hand, conflict is caused by "contingent" reasons. These are conditions rooted in the fabric of society. However, they are hardly ever capable of causing conflicts on their own. On the other hand they are "triggers" of conflict which are the inherent (immediate) causes of 
conflict [27]. [28] Cunningham also supports the argument that the eclectic theories have leverage in explaining conflict. He called them a fusion of the micro and the macro theories. By micro theories, he was referring to the behavioural theories which situate conflict in the individual's subconscious system. By macro theories, he meant the classical theories which situate conflict in inter-group relations. He sought explanation of Northern Ireland's conflict in the merger of both the micro and the macro theories into "hybrid" theories [27]. Of course even these eclectic theories have been criticized, primarily because they do not narrow down conflict to singular causation. This is the reason why it is relevant in Nigerian churches as the causes of conflict in the churches are many as they help to explain some elements of conflict in Nigerian churches' situations. Therefore, the eclectic theories can be contextualized for the understanding of the Nigerian religious conflicts which will also assist in determining the appropriate path to managing and transforming conflicts in the churches.

\section{Literature Review}

\subsection{Church Conflict and Its Effects}

Leadership or church conflict can be understood as a vigorous struggle or disorderly fight with a determination to occupying a leadership position or post by any means possible against the accepted norm or laid down rules, procedure or standard. In other words, it is a desire to become a leader by "fire by force" or "do or die." This is always against the will of majority.

Leadership or church conflict could be between two or group people who are vying for or claiming a particular position of leadership or one person doing everything possible to usurp authority from a legitimate occupant of an office or position. This encompasses all misunderstanding in area of doctrines, monetary matters and clash of personalities over opinions. Some people in the church today have employed diabolical means for them to occupy a given office. Leadership conflict has pitched one denomination against another, one pastor against pastor, member against member, tribe against tribe, one social stratum against another, one region against another, children against parents and so on. There are litigations in some courts today by reason of leadership conflict. As mentioned earlier, congregational or leadership conflict is a struggle, fight or argument between church members or among leaders in order to get something. One of the effects of leadership conflict is that, the fellowship and communion of the church is broken down [30]. Members become suspicious of each other. The church eventually lost its spiritual power. It affects every aspect of the church life such as attendance of programme, collection of offerings, physical development, members become passive and the enthusiasm to do the work of God is drastically reduced. Furthermore, open confrontation has been experienced in some churches during church conflict which led to physical combat, verbal assault in the church and thus police were invited to broker peace. Some churches activities were closed down temporarily because of security reasons. This has resulted 
in disintegration of the church and the establishment of new local churches with the membership of the old ones.

Lack of focus is another effect of conflict. Whenever there is tension or conflict church attention will change. Instead of preaching the gospel, the attention of the church is focused on how to manage crisis. This affects the vibrancy of the church. The time for missions and evangelism will be given to conflict management [31] [32]. According to Aworinde when there is conflict in the church, there will be unnecessary and careless spending. Misappropriation of funds will be the order of the day. In other words, conflict has always affected the vision, mission, and goals of the church. The resources that are supposed to be used positively for the achievement of the laudable goals of the church are utilized to pursue the course of leadership conflict. The energy that ought to be used in the propagation of the gospel is used to attack one another in the attempt to gain superiority.

\subsection{Public Relations Strategies for Conflict Management}

Public Relations help our complex, pluralistic society to reach decisions and function more effectively by contributing to mutual understanding among groups and institutions. It serves to bring private and public policies into harmony.

Public Relations serve a wide variety of institutions in society such as business, trade unions, marital institution, government agencies, voluntary associations, foundations, hospitals, educational and religious institutions. To achieve their goals, these institutions develop effective relationships with different audiences or publics such as employees, Church leaders, members, customers, local communities, shareholders and other institutions within the society [11] [12]. Igben highlighted various public relations strategies being used all over the world in conflict management. Some of them are dialogue, mediation, negotiation, arbitration, community relations and many others [30] [31] [32]. In conflict management, public relations remained a veritable instrument.

Anaeto and Solo-Anaeto [23] identify four public relations strategies in the management of conflict. They are:

1) Collaboration: This involves the use of constructive dialogue by both parties involved in a conflict as means of finding solution to the problem. The interests of both parties are outlined and there is an effort to equitably satisfy all the interests to ensure amicable relationship.

2) Negotiation: This strategy involves a bargain process in which each party in the conflict seeks the absolute satisfaction of its own interest and conceding to any other option. In this strategy there a lot of power play since no party wants to lose in the process. In managing this conflict a middle point is agreed upon and accepted by both parties. The eventual agreement entered into by both parties serves as the document that governs cooperation and relationship between the two. 
3) Mediation: This is a strategy in which a neutral third party comes in to help resolve the conflict between the two parties. The third party is the mediator; he facilitates reconciliation and peace between the parties. He must be a confidential and a respectable entity among the disputants in order to succeed in the task.

4) Arbitration: In this strategy, both party parties submit their arguments and positions to a neutral party who is empowered to act as judge. Whatever judgment he pronounces, the parties are bound by law to accept it. By this strategy, one party wins while the other loses. Hence the above three theories justify the reasons of using more than one theory to explain conflict situations in a church setting because of different approach to conflict management.

\section{Methodology}

The methodology used for this paper is in-depth interview. The interview technique was used to elicit information from three senior pastors-in the Headquarters church and Ekpan branch pastor of Agape Gospel Mission.

\section{Data Collection and Analysis}

\section{Interview}

[33] [34] The in-depth interview technique according to Wimmer and Dominick cited in Edafejirhaye' work is a hybrid of one-on-one interview that promotes wealth of details information and it allows interviewer to form more questions out of questions in the process of interviewing respondent based on respondent's answer [14] [20]. This method could accommodate between 1 to 20 respondents. Tape recorder was used to gather the data and later edited. The respondents of the study were 3 senior pastors of Agape Gospel Mission within the headquarters church. Purposive sampling of Pastors who have spent at least 20 years in the ministry was done intentionally in order to elicit vital information based on their experiences.

\section{Data Presentation}

The data for this study are presented in a qualitative format. The following are the respondents interviewed.

\section{Respondent 1}

Respondent 1 is the presiding Bishop of Agape Gospel Mission in Nigeria. He is one of the founding fathers of the Mission in 1983. He has been working in the headquarters church for 35 years.

\section{Respondent 2}

Respondent 2 is one of the senior Pastors in the Headquarters church coordinating Effurun/Ekpan zone. He has been working in the Mission for 28 years.

\section{Respondent 3}

Respondent 3 is the resident pastor of the Headquarters church. He has been working in the Mission for 26 years.

Research Question 1

What are the major causes of conflict in Agape Gospel Mission? 


\section{Respondent 1}

According to respondent 1, Different kinds of allegations over immorality, financial misappropriation, transfer of pastors and frequent friction among top leaders on spiritual matters are some of the causes of conflict.

\section{Respondent 2}

Respondent 2 on the hand sees causes of conflict in the Mission are, imposition of views, ideas and conflict of opinion on pastors. He went further to say that some leaders are seen as rude and rebellious who want to override leadership decisions. To him it is a rebellious attitude towards constituted authority.

\section{Respondent 3}

Respondent 3 identifies two major causes of conflict in the church. They are:

Leaders act of sowing seed of discord among the brethren and attitude of leaders not hearing from contending parties before taking vital decisions on particular issue. (see Appendix).

\section{Research Question 2}

To what extent Agape Gospel Mission uses Public Relations strategies to manage conflict?

\section{Respondent 1}

"Whenever conflicts surface I rely on the Holy Spirit to direct me on what do after prayer. I hear from both parties then apply negotiation, persuasion, prayer and the word of God in handling such situations. Many a times I use Jesus' principles of conflict resolution enshrined in Matthew 18:15-18. In other cases I use public relations strategies such as personal dialogue, persuasion, negotiation and when dialogue fails I use external party (arbitration)." (see Appendix)

From the above view of respondent 1 , it could be deduced that not only he depends on the Holy Spirit and the word of God for conflict management, he also use Public relations strategies such as dialogue, negotiation, persuasion and arbitration.

\section{Respondent 2}

"Although I am not a professional public relations officer, the styles I use in conflict management are not different from the professionals. I employ the law of fair hearing for both party in a separate occasion, then later hear from both parties in a round table discussion. After this, I make the parties negotiate terms of peace and reconciliation. When conflict is between highly placed ministers of the gospel the Pentecostal Fellowship of Nigeria (PFN) is usually invited to intervene in the matter as an arbitrator" (see Appendix).

The above points of respondent 2 , shows that he also use some elements of public relations strategies in conflict management. Some PR strategies mentioned are; the act of fair hearing, Dialogue, negotiation and arbitration.

\section{Respondent 3}

"Fasting and prayer is my first tool of conflict management. After this I call the parties involved for dialogue and if it is possible, depending on the kind of conflict I press for mutual sacrifice from both to allow amicable settlement" (see Appendix in Page). 
Respondent 3 combines spiritual tools with public relations strategies for conflict management. Some PR strategies he pointed out are dialogue, persuasion, lobbying and self denial (sacrifice) to promote amicable settlement.

\section{Summary of Findings}

From the above presentation of data, one can see the major causes of conflict in the church matched with the literature review. The strategy of conflict management in the church is similar to that of Public relations (Igben, 2009). Some of the tools of public relations Agape Gospel Mission uses are fair hearing, personal dialogue, persuasion, lobbying, negotiation, self-denial and arbitration.

\subsection{Conclusion}

From the above data one can see that conflict is an inevitable factor in human relations. Spirituality does not stop the manifestation of conflict even in the church; hence measures to manage it has to be put in place by God and Public Relations field of communication for the benefit of humanity and peaceful co-existence. We should explore and exploit these factors for conflict transformation.

\subsection{Recommendations}

The following recommendations were harvested from the interview:

1) That Pentecostal churches vis-a-vis all churches should copy Agape Gospel Mission and adopt principle of fair hearing, dialogue, persuasion, negotiation and arbitration as ways of managing conflict in their churches.

2) That the biblical principles of managing conflict documented in the holy book-Bible should be used from time to time in resolving and managing conflict in the church.

3) The principle of fair hearing, justice and mutual sacrifice should be adopted to promote peace and tranquility in the house of God.

4) And above all where disciplinary action is needed the church leaders should be bold enough to take action promptly according to the scripture.

\section{Acknowledgements}

We hereby acknowledged the contributions of the following people and all sources of our secondary data to this work. Prof. S. E Alao, Dr, A. Alao (of Adeleke University); Rev. Ovie Dawene, Rev R.E Govina and Rev. V. Eziatu (of Agape Gospel Mission Inc.).

\section{Conflicts of Interest}

The authors declare no conflicts of interest regarding the publication of this paper.

\section{References}

[1] Ibrahim, R.A. (2001) Strategic Public Relations Functions in Collective Bargaining 
and Conflict Resolution in a Volatile Nigerian Economy. Public Relations Journal, 2,67 .

[2] Black, S. (1990) Introduction to Public Relations. Midino Press, London.

[3] Nwosu, I.E. (1995) Public Relations Management: Principles, Issues, and Application. Dominican Publishers, Aba, 32.

[4] Akinwumi, O. (2004) Crises and Conflicts in Nigeria: A Political History since 1960. Transaction Publishers, London.

[5] Hoff, J.L. (1973) Conflict Management: An Organizational Principle. Christian Ministry Press, New York. http://cain.ulst.ac.uk/conflict/cunningham.htm

[6] Cosers, L. (1956) The Functions of Social Conflict. The Free Press, London, 8.

[7] Ledingham, J.A. (2003) Explicating Relationship Management as a General Theory of Conflict. In: Lee, R. and Marty, M., Eds., Religion and Conflict, University Press, New York, 4.

[8] Oji, M. (2009) Niger Delta Citizen Participation in Conflict Management through Involvement in Development Programmes. In: Des Wilson, Ed., Communication Approaches to Peace Building in Nigeria, African Council for Communication Education, Nairobi, 433-455.

[9] Deutsch, M. (1973) The Resolution of Conflict, Constructive and Destructive Processes. Yale University Press, New Haven. https://doi.org/10.1177/000276427301700206

[10] Laderach, J.P. (1995) Preparing for Peace: Conflict Transformation across Cultures. Syracuse University Press, Syracuse.

[11] Igben, H.G.O. (1997) Public Relations Fundamentals. COEWA Publishers, Effurun, 12.

[12] Igben, H.G.O. (2009) Public Relations and Conflict Management in the Niger Delta. In: Des Wilson, Ed., Communication Approaches to Peace Building in Nigeria, African Council for Communication Education, Nairobi, 267-288.

[13] Haywood, R. (1984) All about Public Relations. McGraw-Hill Book, London, 4.

[14] Agape Gospel Mission. http://www.agapegospelmission.org

[15] Edafejirhaye, I.V. (2015) Conflict Management in Pentecostal Churches. Department of Mass Communication, Babcock University, Ilisan-Remo.

[16] Fernandez, P.R (2009) Conflict Resolution. New Delhi Press, New Delhi.

[17] Duval, M.L. (1928) Baptist Missions in Nigeria. Education Press, Richmond.

[18] Ojo, M.A. (1995) Stone, Moses Ladejo and Ebenezer Baptist Church. CSS Bookshops Ltd., Lagos.

[19] Defleur, M.L. and Ball-Rokeach, S.T. (1982) Theories of Mass Communication. Longman, New York, 196.

[20] Wimmer, R.D. and Dominick, J.R. (2006) Mass Media Research: Introduction. Thomson Wadsworth Publishing, Belmont.

[21] Zartman, W.I. (1991) Conflict Resolving in Africa. The Bookings, Washington DC.

[22] Grunig, J.E. and Hunt, T. (1984) Managing Public Relations. Rinehart and Winston, New York.

[23] Anaeto, S.G. and Solo-Anaeto, M. (2009) Conflict Reporting as an Instrument for Conflict Management in the Niger Delta Area of Nigeria. In: Des Wilson, Ed., Communication Approaches to Peace Building in Nigeria, African Council for Communication Education, Nairobi, 347-358. 
[24] Mogu, V. (2009) Strategic Public Relations in the Niger Delta Region. In: Des Wilson, Ed., Communication Approaches to Peace Building in Nigeria, African Council for Communication Education, Nairobi, 375-394.

[25] Jefkins, F. (1992) Public Relations. 4th Edition, Potman Publisher, London.

[26] Nkwocha, J. (1999) Effective Media Relations: Issues and Strategies. Zoom Lens Publishers, Lagos, 20.

[27] Akanji, I.A. (2011) Towards a Theology of Conflict Transformation: A Study of Religious Conflict in Contemporary Nigerian Society. PhD Thesis, University of Edinburgh, Edinburgh.

[28] Cunningham, W.G. (1998) Conflict Theory and the Conflict in Northern Ireland. PhD Thesis, University of Edinburgh, Edinburgh.

[29] Skinner, B.F. (1974) About Behaviourism. Jonathan Cape Ltd., London, 42.

[30] Yusuf, B. (2012) Challenges Facing the Contemporary African Church. ZOE Graphic, Kaduna, 33.

[31] Aworinde, S. (1993) The Church in Crisis. Ebenezer Press, Ibadan, 27.

[32] Awojobi, P.O. (2011) Church Management. Kingdom Power Communications, Ilorin, 41 .

[33] Nigerian Baptist Convention. http://www.nigerianbaptist.org

[34] Israel, H.C. (2014) Pentecostal Influences on African Independent Churches: A Case Study of Cross River State, Nigeria. UNN. University Press, Nnsukka. 


\section{Appendix}

In depth Interview Questions and edited transcript of respondents' responses

\section{Respondent 1}

Respondent 1 is the presiding Bishop of Agape Gospel Mission in Nigeria. He is one of the founding fathers of the Mission in 1983. He has been working in the headquarters church for 32 years.

\section{Respondent 2}

Respondent 2 is one of the senior Pastors in the Headquarters church coordinating Effurun/Ekpan zone. He has been working in the Mission for 28 years.

\section{Respondent 3}

Respondent 3 is the resident pastor of the Headquarters church. He has been working in the Mission for 21 years.

\section{Question 1}

From your personal experience as a pastor in Agape Gospel Mission how did you see the issues of conflict in the church?

\section{Respondent 1}

I, as one of the foundational leaders of this church, I would like you to know that conflict is a daily issue among leaders but God's grace is keeping us going. One of such conflicts is the one we experienced in the year 1993 which almost make me to resign from the Mission because of different kinds of allegations over immorality, finance and constant misunderstanding among top leaders on spiritual matters.

\section{Respondent 2}

I relate with people of different personalities and characters for over 28 years now so I know what human beings are in terms conflict and peaceful co-existence. Sometimes the most spiritual people can give leaders unexpected headache by try to impose their view, idea and knowledge on pastor. Some want to override leadership decisions. It takes a pastor with divine wisdom to manage such people.

\section{Respondent 3}

I worked in other churches before coming to Agape Gospel Mission. Right now I have spent over 21 years here. My experience in all these years made me to understand that people are the same everywhere. They may be church members or church leaders no matter the spirituality, they are the same. The colour of the skin or nationality does not make any difference. For instance, the major conflict experienced in this Mission in 1993 was engineered by an American whom we all look up to as a father. Looking at his spiritual background one can hardly believed that he could allow himself to be used to cause disharmony among the people by sowing seed of discord and the same time refuse to allow fair hearing from the other party.

Question 2 
What was the nature of conflicts your church has been experiencing of late?

\section{Respondent 1}

Over the years we had different types of conflicts. Some are marital issues, another is leadership tussle, while the rest are on personal ideas, views, doctrines and morality.

\section{Respondent 2}

Like any other churches this Mission has been experiencing conflict among members, church workers and church top leadership. Some of these conflicts are minor issues that could be address within, but few others are issues of leadership incompatibility in terms of spiritual performance duty and the finance are being managed.

\section{Respondent 3}

Marital issues top the list of conflict in the church. Some of these are issues of immorality among members, marital disagreement between couples, financial and church project management.

\section{Question 3}

What were the causes and effects of those conflicts in the Mission?

\section{Respondent 1}

What I see as the causes of those conflicts in the Mission could be traced to human factor, personality differences and different ways people view events. The effects of these conflicts could be observed in retarded growth of the church, the breaking of the headquarters church and some of the branches in other cities and villages. The end result was financial sprain on the entire Mission.

\section{Respondent 2}

From personal experience, I discovered that insubordination is one of the causes of conflict in Pentecostal churches. In a situation where younger pastors refused to obey higher authority or talk good about leaders the result is always conflict. Such actions always lead to breaking of churches to form another. Another cause of conflict I found out is the issues of remuneration. Many churches are not paying their pastor well. Many are tempted to cause disaffection among brethren seeing much money being raised from time to time in the church and they are being paid peanut. This disaffection could cause division among members and leaders and at the end brings serious disharmony. This Mission has had enough of these in these few years.

\section{Respondent 3}

Some of the causes of conflicts in this Mission as I can recall are rebellious attitude, financial mismanagement, leadership struggle, Envy and lack of attention to village branches. The effects of the above mentioned are seen in the Mission's evangelical effort and general growth of the Mission.

\section{Question 4}

Does your church have public relations department?

\section{Respondent 1}

The Church may not have Public relations outfit but Welfare Committee does the work of public relations by meeting the needs of the less privileged, aged, the 
sick and others. The Pastors, deacons/deaconesses and other church workers also perform the duty of public relations officers.

\section{Respondent 2}

You know my duty as Pastor is to relate to all categories of people within and outside the church. Therefore, the church herself is a public relations organization because we care about people's spiritual, physical, financial and emotional wellbeing. Besides, there is board of deacon and deaconess that handles all issues of physical needs of members.

\section{Respondent 3}

The work of the resident pastor is more or less of public relations officer. I do not see need to employ or create Public relations department. But I do use Public relation tools in conflict management.

\section{Question 5}

Which Public relations strategies do you employ when conflicts surface?

\section{Respondent 1}

Whenever conflicts surface I rely on the Holy Spirit to direct me on what do after prayer. The word of God is my ever ready resource for handling such situation. Many a times I use Jesus' principles of conflict resolution enshrined in Matthew 18:15-18. In other cases I use public relations strategies such as personal dialogue and when dialogue fails I use external party (arbitration).

\section{Respondent 2}

Although I am not a professional public relations officer, the styles I use in conflict management are not different from the professionals. I employ the law of fair hearing for both parties in a separate occasion, then later hear from both parties in a round table discussion. After this, I make the parties negotiate terms of peace and reconciliation. When conflict is between highly placed ministers of the gospel the Pentecostal Fellowship of Nigeria (PFN) is usually invited to intervene in the matter.

\section{Respondent 3}

Fasting and prayer is my first tool of conflict management. After this I call the parties involved to dialogue and if it is possible, depending on the kind of conflict I press for mutual sacrifice from both to allow amicable settlement.

\section{Question 6}

What are the principles put in place in your Mission in managing conflict?

\section{Respondent 1}

We have no special rules or laws by which conflict is addressed. We use the word of God as our guide.

\section{Respondent 2}

We have contingent approach to all forms of conflicts being guided by the scriptures and the Holy Spirit. The way one pastor in a local church handle a particular case may be different from another but using the scripture as guide.

\section{Respondent 3}

The Bible remained our guiding principle in addressing all types of conflicts 


\section{Question 7}

What are your recommendations for other Pentecostal Churches?

\section{Respondent 1}

I hereby recommend peaceful resolution of conflict through dialogue before they start to cause havoc in the church. Leaders should develop the art of hearing matter from the rightful parties before taking side or action.

\section{Respondent 2}

Spiritual leaders should follow the footstep of Jesus Christ and His biblical ways of conflict management. Churches that have the means should employ the services of professional public relations officers.

\section{Respondent 3}

I recommend that every pastor whether in the city or the village should see himself as a potential public relations officer. Therefore, public relations strategies should be used in the church for conflict management. Strategies such as mediation, dialogue, negotiation, arbitration, church relations, community and media relations. 